\title{
Influence of nitrate availability on the distribution and abundance of heterotrophic bacterial nitrate assimilation genes in the Barents Sea during summer
}

\author{
Andrew E. Allen ${ }^{1,2,3, *}$, Melissa G. Booth ${ }^{2}$, Peter G. Verity ${ }^{2}$, Marc E. Frischer ${ }^{2}$ \\ ${ }^{1}$ University of Georgia, Institute of Ecology, Athens, Georgia 30602, USA \\ ${ }^{2}$ Skidaway Institute of Oceanography, Savannah, Georgia 31411, USA \\ ${ }^{3}$ Present address: Department of Geosciences, Guyot Hall, Princeton University, Princeton, New Jersey 08544, USA
}

\begin{abstract}
In a transect across Norwegian coastal waters and the Barents Sea to approximately $78^{\circ} \mathrm{N}$, distinct patterns in the distribution and abundance of bacterial assimilatory nitrate reductase (nasA) genes were observed in relation to $\mathrm{NO}_{3}{ }^{-}$availability and bacterial dissolved inorganic nitrogen utilization. A real-time PCR assay, developed for a group of nasA genes characteristic of Marinobacter sp., which are a common group of nitrate-assimilating bacteria in the marine environment, indicated that the nasA gene abundance of Marinobacter sp. was positively correlated with $\mathrm{NO}_{3}{ }^{-}$concentration. At 5 stations sampled, Marinobacter sp. nasA gene abundance was, on average, 8-fold higher at $80 \mathrm{~m}$ compared to $5 \mathrm{~m}$ depth, relative to total bacteria. Bacterial productivity, bacterial biomass, chlorophyll ${ }^{a}, \mathrm{NH}_{4}{ }^{+}$, and $\mathrm{NO}_{3}{ }^{-}$were modeled as independent variables in a partial least-squares regression model to determine how well each variable predicted the variation in nasA community structure, defined by terminal restriction-length-fragment polymorphism analysis. $\mathrm{NO}_{3}{ }^{-}$concentration was the best predictor, by a factor of 10, of the variability associated with nasA community structure. In a companion study of ${ }^{15} \mathrm{NO}_{3}{ }^{-}$and ${ }^{15} \mathrm{NH}^{+}{ }_{4}$ uptake across the same transect, conducted at the same time as this study, bacteria were relatively more important in terms of total community uptake in the marginal ice zone, where $\mathrm{NO}_{3}{ }^{-}$levels were high, compared to samples from the North Atlantic, where $\mathrm{NO}_{3}{ }^{-}$concentrations were lower. Results presented here indicate that $\mathrm{NO}_{3}{ }^{-}$availability and patterns of $\mathrm{NO}_{3}{ }^{-}$utilization are correlated with nasA community structure variability and abundance.
\end{abstract}

KEY WORDS: Assimilatory nitrate reductase $\cdot$ Nitrogen cycle $\cdot$ nasA $\cdot$ Marine bacteria $\cdot \mathrm{PCR}$. T-RFLP $\cdot$ Real-time PCR

\section{INTRODUCTION}

Heterotrophic bacterial utilization of dissolved inorganic nitrogen (DIN), if significant, would have profound effects on the fluxes of $\mathrm{N}$ and $\mathrm{C}$ in the water column (Kirchman et al. 1992, Kirchman 1994). $\mathrm{NO}_{3}^{-}$ uptake by heterotrophic bacteria is especially important because of its potential impact on estimates of new production and on the relationship between new production and carbon export out of the euphotic zone (Legendre \& Grosselin 1989, Kirchman 2000). However, relationships between the diversity and distribution of nitrate-assimilating bacteria and patterns of
$\mathrm{NO}_{3}{ }^{-}$availability and bacterial DIN uptake have not been investigated.

Based on ${ }^{15} \mathrm{~N}$ measurements of bacterial DIN assimilation across a transect in the Barents Sea from North Atlantic waters into the marginal ice zone (MIZ), bacteria accounted for 16 to $40 \%$ of the total $\mathrm{NO}_{3}{ }^{-}$uptake (Allen et al. 2002). In 12 out of 15 experiments bacteria were responsible for a higher percentage of total $\mathrm{NO}_{3}{ }^{-}$ uptake compared to total $\mathrm{NH}_{4}{ }^{+}$uptake (Allen et al. 2002). Several other studies have also documented high levels of $\mathrm{NO}_{3}{ }^{-}$utilization by bacteria (Kirchman 2000, Middelburg \& Nieuwenhuize 2000, Joint et al. 2002, Rodrigues \& Williams 2002, Ovreas et al. 2003). 
Despite the importance of bacterial assimilation of $\mathrm{NO}_{3}{ }^{-}$to the introduction of organic $\mathrm{N}$ into the microbial food web and to geochemical mass balances, it is a process that has received very little attention in models of pelagic $\mathrm{C}$ and $\mathrm{N}$ fluxes (Fasham et al. 1990, Boynton et al. 1995, Haupt et al. 1999, Olivieri \& Chavez 2000, Dadou et al. 2001).

The purpose of this study was to investigate the variability associated with the diversity and abundance of populations of nitrate-assimilating bacteria across water masses with contrasting $\mathrm{N}$-cycling regimes. Bacterial assimilatory nitrate reductase genes (nasA) were assayed for diversity and abundance in surface waters $(5 \mathrm{~m})$ and deeper in the euphotic zone $(80 \mathrm{~m})$, across a transect that began in North Atlantic waters of the southern Barents Sea, crossed the Polar Front, and ended in the MIZ dominated by Arctic water. Oceanographic data collected from the North Atlantic segment of the transect revealed signs of nitrogen limitation and a post-bloom-phase plankton community, while MIZ waters were in pre-bloom phase and not DIN-limited (Allen et al. 2002). We address the hypothesis that differences in $\mathrm{NO}_{3}{ }^{-}$concentrations and $\mathrm{NO}_{3}{ }^{-}$ uptake rates are reflected in the variability associated with nasA population community structure and abundance.

T-RFLP (terminal restriction-fragment-length polymorphism), clone library analysis, and real-time PCR for nas $A$ were applied to the same water samples for which the rates and amount of DIN utilization by bacterioplankton were previously reported (Allen et al. 2002). In the geochemical analyses of these samples, DIN accounted for 5 to 10 times more of the bacterial $\mathrm{N}$ budget in the MIZ compared to North Atlantic waters. Also, bacteria were generally responsible for a much higher percentage of total $\mathrm{NO}_{3}{ }^{-}$uptake at $80 \mathrm{~m}$ compared to at $5 \mathrm{~m}$ and in MIZ waters compared to North Atlantic waters (see Table 1). MIZ stations (III, IV, and

Table 1. Percent ${ }^{15} \mathrm{NO}_{3}{ }^{-}$uptake by bacteria $(<0.8 \mu \mathrm{m}$ fraction). Data summarized from Allen et al. (2002)

\begin{tabular}{|lccll|}
\hline Stn & $\begin{array}{c}\text { Depth } \\
(\mathrm{m})\end{array}$ & $\begin{array}{c}\text { \% total } \mathrm{NO}_{3}{ }^{-} \\
\text {uptake by bacteria }\end{array}$ & {$\left[\mathrm{NH}_{4}{ }^{+}\right]$} & {$\left[\mathrm{NO}_{3}{ }^{-}\right]$} \\
\hline I & 5 & 2.2 & 0.95 & 0.03 \\
& 80 & 31.5 & 2.46 & 9.30 \\
II & 5 & 25.8 & 0.69 & 0.75 \\
& 80 & 26.1 & 2.6 & 6.65 \\
III & 5 & 17.5 & 0.93 & 0.06 \\
& 80 & 40.6 & 3.80 & 7.67 \\
IV & 5 & 39.1 & 0.19 & 4.83 \\
& 80 & 40.2 & 3.85 & 8.52 \\
V & 5 & 27.2 & 0.33 & 4.44 \\
& 80 & 44.4 & 0.20 & 9.89 \\
& & & & \\
\hline
\end{tabular}

V), therefore, were selected for clone library analysis, in order to extend the characterization of nas $A$ sequence diversity to samples collected from waters where bacteria are known to contribute significantly to $\mathrm{NO}_{3}{ }^{-}$assimilation.

In a separate previous study, bacterial strains containing the nasA gene were isolated from Barents Sea waters, and their respective 16S rRNA and nasA genes were sequenced and characterized (Allen et al. 2001). A Marinobacter sp. isolate from the Barents Sea contained a nasA gene sequence very similar to the majority of clones recovered from the Sargasso Sea and South Atlantic Bight clone libraries. Also, we observed a putative Marinobacter sp. peak in most of the Barents Sea T-RFLP profiles, and primers specific for the Marinobacter sp. cluster of nasA genes produced robust PCR products from all of the Barents Sea samples, whereas primers targeted to nasA genes belonging to other clades did not consistently yield strong products. Therefore, a real-time PCR assay specific for Marinobacter sp. nasA genes was developed, to quantify the ecological importance of this group of nasA genes in relation to environmental variables, including nutrient concentrations and DIN-utilization rates.

\section{MATERIALS AND METHODS}

Studies were conducted during a cruise (ALV-3) aboard the RV 'Jan Mayen' in June/July 1999. Five stations were sampled along a 19 station transect (Fig. 1), beginning in complete ice cover on 1 July $\left(78^{\circ} 13.67^{\prime} \mathrm{N}, 34^{\circ} 23.02^{\prime} \mathrm{E}\right)$ and ending in coastal waters on 9 July $\left(73^{\circ} 47.99^{\prime} N, 31^{\circ} 44.10^{\prime} \mathrm{E}\right)$. See Allen et al. (2001) for a detailed description of the sampling and collection method.

DNA collection. Total community bacterial DNA was extracted and purified from 401 water samples collected at depths of 5 and $80 \mathrm{~m}$ at each of the 5 stations. The water samples were pooled from 4 Niskin bottles (each 10 1), DNA was extracted and purified using the Ultra Clean Mega Prep soil DNA kit (Mo Bio Laboratories). Nested PCR with heterotrophic bacteria-specific nas $A$ primers (Table 2), targeted to an 800 bp fragment of the nasA gene, was performed as previously described (Allen et al. 2001).

T-RFLP. The restriction enzymes DdeI, MboI, and RsaI were selected for T-RFLP analysis because this combination of enzymes discriminates between different clades of nasA genes: unweighted pair group method with arithmetic mean (UPGMA) phylogenetic trees generated from predicted T-RFLP patterns of nasA genes digested with $D d e I, M b o I$, and RsaI retain coherent clusters of the major groups of nasA genes in the database (data not shown). The upstream primer, 


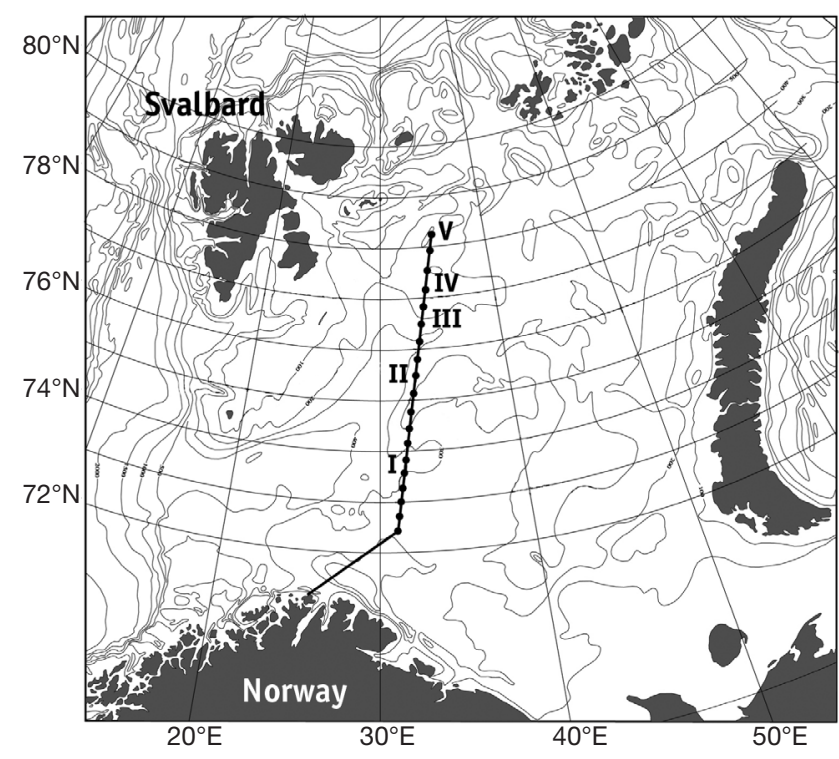

Fig. 1. Cruise track in the Barents Sea of the RV 'Jan Mayen' in July 1999 (dots, locations of 19 transect stations; I to V, locations of major sampling stations where samples for this study originated)

nas964 (Allen et al. 2001), was labeled at the 5'-end with a phospohamadite-linked D4 dye (Beckman Coulter). Primers were synthesized by Invitrogen. A nested $25 \mu \mathrm{l}$ PCR reaction was performed, as described above, with $50 \mathrm{ng}$ of template DNA added to 3 firstround reactions; each first-round reaction was then used as a template in 4 second-round reactions for a total of 12 PCR reactions for each DNA sample. Firstand second-round reactions contained 500 pmol of primer and ran for 30 cycles.

After amplification, $25 \mu \mathrm{l}$ PCR reactions were loaded into separate wells on a $0.8 \%$ agarose gel containing $1 \times$ GelStar nucleic acid stain (BMA), and separated by gel electrophoresis at $60 \mathrm{~V}$ for 3 to $5 \mathrm{~h}$ in $1 \times$ TAE buffer at room temperature. The approximately $800 \mathrm{bp}$ nasA PCR products were then visualized on a Dark Reader (Clare Chemical Research), which excites fluorophores between 420 and $500 \mathrm{~nm}$. A Dark Reader was used in place of a UV transilluminator because UV light was found to damage the D4 fluorescent label. nasA PCR products were then excised from the gel, purified, eluted, and pooled using Quantum Prep DNA Gel Extraction Spin Columns (Bio-Rad). The concentration of the purified and pooled PCR product was then estimated by fluorometry with a Turner Design TD-700 fluorometer (Turner Designs) using a PicoGreen dsDNA Quantitation Kit (Molecular Probes).

A total of $50 \mathrm{ng}$ of purified PCR product was digested separately in triplicate with $10 \mathrm{U}$ of restriction enzymes: DdeI, MboI, and RsaI (New England Biolabs). Digests were incubated at $37^{\circ} \mathrm{C}$ for $5 \mathrm{~h}$ in buffer provided by the manufacturer. Digested DNA was precipitated with $0.1 \mathrm{vol}$ of $3 \mathrm{M}$ sodium acetate and $2 \mathrm{vol}$ of $95 \%$ ethanol, washed twice with $70 \%$ ethanol, dried, and resuspended in $40 \mu \mathrm{l}$ of deionized formamide with $0.5 \mu$ of CEQ DNA Size Standard-600 (Beckman Coulter). After denaturing for $120 \mathrm{~s}$ at $90^{\circ} \mathrm{C}$, samples were injected into the capillary for $30 \mathrm{~s}$ at $2.0 \mathrm{kV}$ and then separated for $70 \mathrm{~min}$ at $4.8 \mathrm{kV}$. Capillary electrophoresis was performed on a Beckman CEQ 2000XL DNA Analysis System with a CEQ capillary array (33 cm long, $75 \mu \mathrm{m}$ internal diameter) and CEQ linear polyacrylamide denaturing gel (LPA-1). For each enzyme used a complete list of the possible peaks was complied. T-RFLP profiles were scored for the presence or absence peaks. To account for small variations in migration between samples, peaks from different profiles with $<1$ base difference were considered the same.

PCR amplification and cloning. PCR products were agarose gel-purified, and clone libraries were constructed from 5 and $80 \mathrm{~m}$ at Stn III, and $80 \mathrm{~m}$ at Stns IV and V, as described by Allen et al. (2001). Then, 25 clones, which were confirmed to contain the $\sim 800 \mathrm{bp}$ putative nasA gene amplicon, were sequenced from the library constructed from the $80 \mathrm{~m}$ Stn IV sample, and 10 such clones from each of the libraries were constructed from the 5 and $80 \mathrm{~m}$ Stn III and $80 \mathrm{~m}$ Stn V

Table 2. Oligonucleotide primers used for heterotrophic-specific nasA, Marinobacter sp. nasA, and 16S rRNA genes

\begin{tabular}{|llrl|}
\hline Primer & \multicolumn{1}{c|}{$\begin{array}{c}\text { Sequence } \\
\left(5^{\prime} \text { to } 3^{\prime}\right)\end{array}$} & $\begin{array}{c}\text { PCR product } \\
\text { size (bp) }\end{array}$ & Application \\
\hline nas22 & TGYCCNTAYTGYGGNGT & 1911 & nasA/narB PCR amplification \\
nas964 & CARCCNAAYGCNATGGG & 771 & nasA PCR amplification \\
nasA1735 & ATNGTRTGCCAYTGRTC & nasA/narB PCR amplification \\
nas1933 & CARTGCATNGGNAYRAA & 771 & 16S rRNA forward \\
$932 \mathrm{~F}$ & CGCACAAGCRGYGGAGYATGTG & 1911 & 16S rRNA reverse \\
1062R & CACRRCACGAGCTGACGA & 131 & Marino sp. nasA forward \\
Mar259F & GCGTTGTCCCACCGTGATTGT & 131 & Marino sp. nasA reverse \\
Mar373R & ATTGGTGACGGTGCCATCCTT & 115 & 115 \\
\hline
\end{tabular}


samples. nasA amino acid sequences were aligned using the CLUSTAL W (Version 1.7) multiplesequence-alignment algorithm (Thompson et al. 1994). Neighbor-joining phylogenetic trees were inferred and drawn by using the TREECON software package (Version 1.3b) (Van de Peer \& De Wachter 1997), with the Kimura 2-parameter model for inferring evolutionary distances. Bootstrap estimates (100 replicates) of confidence intervals were also made using the algorithms available in the TREECON package.

Quantitative real-time PCR. A primer pair suitable for use in a SYBR green real-time PCR assay (Higuchi et al. 1991, Wittwer et al. 1997) specific for the clade of bacterial nasA genes typified by a Marinobacter sp. isolate was designed (Table 2). In order to estimate the contribution of Marinobacter-like nasA genes as a percentage of the total bacteria, an additional set of universal eubacterial 16S rDNA primers was designed and used in parallel to the nasA primers, so that the relative abundance of nasA genes could be estimated in the water column (Table 2). Expressing Marinobacter-like nasA gene abundance as a percentage of total bacteria also controlled for variability in DNA extraction. Marinobacter sp. nasA primer design was facilitated by using the software package Primer Premier (Version 5.0, Premier Biosoft International). Criteria for optimal primer pairs suitable for the SYBR green PCR assay included a GC content of 40 to $60 \%$, a length of at least $18 \mathrm{bp}$, and a resulting PCR product of $<200 \mathrm{bp}$ with 1 melting domain.

Q-PCR assays were performed using a Bio-Rad iCyclerIQ Real-Time PCR Detection System. Reactions were performed in a 96-well plate, with each reaction well containing $12.5 \mu \mathrm{l}$ of $2 \times$ QuantiTech SYBR Green Master Mix (Qiagen), $0.2 \mu \mathrm{M}$ concentration of each forward and reverse primer, $100 \mathrm{ng}$ of DNA, and water to $25 \mu \mathrm{l}$. Amplification cycle conditions were $95^{\circ} \mathrm{C}$ for $10 \mathrm{~min}$, followed by 25 cycles for $16 \mathrm{~S}$ rDNA PCR or 30 cycles for Marinobacter nasA PCR of $95^{\circ} \mathrm{C}$ for $15 \mathrm{~s}$, $58^{\circ} \mathrm{C}$ for $10 \mathrm{~s}$, and $72^{\circ} \mathrm{C}$ for $1 \mathrm{~min}$. Because the melting curve of a product is dependent on its GC content, length, and sequence, specific amplification can be distinguished from nonspecific amplification by examining the melting curve (Ririe et al. 1997). Therefore, amplification was followed immediately by a meltcurve thermal profile, which was $65^{\circ} \mathrm{C}$ for $1 \mathrm{~min}$, followed by 125 cycles of $0.2^{\circ} \mathrm{C}$ increments each for $10 \mathrm{~s}$. In each 96-well plate, a dilution series of the plasmid standard for the respective target gene was run along with the unknown samples. Each sample and standard was run in triplicate, and all reactions were repeated at least 3 times independently to evaluate the reproducibility of the results.

Multivariate statistics. Partial least-squares (PLS) regression and principal component analysis (PCA) was performed using the Unscrambler 7.6 software package (CAMO). Before analysis, all variables were autoscaled; geometric means were centered to zero, and all data were normalized for standard deviation. Full cross validation was used in the modeling procedure, 1 sample being omitted at a time. In PLS regression, the regression coefficient for each independent or environmental variable expresses the link between variability in that variable and the variation associated with a particular response variable. The independent variables used for analysis were chlorophyll $a_{\text {, bac- }}$ terial biomass (estimated based on cell abundance), bacterial productivity (estimated via leucine incorporation), percent of metabolically active bacteria estimated by the vital stain and probe method (VSP) (Howard-Jones et al. 2000), and the concentration of $\mathrm{NO}_{3}{ }^{-}$and $\mathrm{NH}_{4}{ }^{+}$. These measurements were previously reported in Howard-Jones et al. (2002) and Allen et al. (2002). Each of these parameters was treated as an independent variable, and the populations of T-RFLP fragments from the digests for each sample were modeled as dependent variables.

Sequencing. Sequences were determined by automated sequencing with a Beckman CEQ 2000XL DNA Analysis System. Sequencing reactions were facilitated by using a CEQ DTCS dye terminator cycle sequencing quick start kit with standard M13F- and M13R-vector-targeted sequencing primers, following the protocol recommended by the manufacturer (Beckman Coulter). Sequence analysis was accomplished using Beckman CEQ 2000XL Sequence Analysis software, Version 4.3.9.

\section{RESULTS}

\section{T-RFLP analysis of nasA genes in Barents Sea samples}

Nearly identical electropherogram profiles were generated from triplicate digests for each pooled PCR reaction with each restriction enzyme (data not shown). Taken together, the restriction enzymes DdeI, MboI, and RsaI generated 72 unique putative terminal restriction fragments (TRF) for all of the samples analyzed. In general, there were more TRFs associated with the samples collected at the MIZ stations (III, IV, V) compared to the North Atlantic stations (I and II) and at $80 \mathrm{~m}$ compared to $5 \mathrm{~m}$ (Fig. 2). As averages between the data collected for 5 and $80 \mathrm{~m}$ samples, there were $23,13,43,30$, and 36 TRFs at Stns I to V, respectively. PCA was performed using the presence and absence of terminal-restriction-fragment peaks as input variables. PCA revealed a statistically significant separation between nasA populations sampled from North Atlantic waters compared to those in the MIZ, but did 


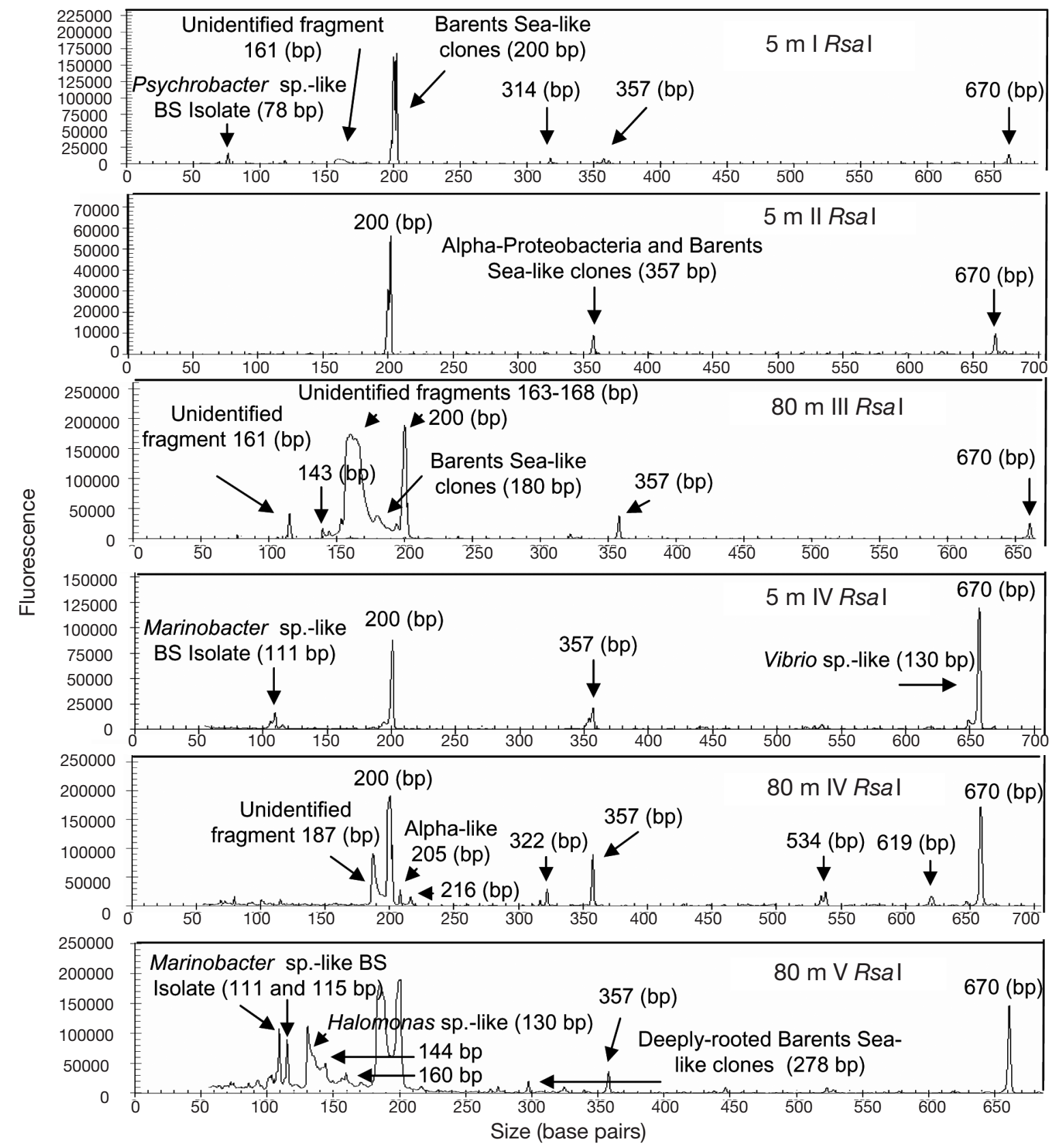

Fig. 2. Representative T-RFLP (terminal restriction-fragment-length polymorphism) fingerprints of different stations and depths for one of the restriction enzymes, RsaI, used in this study. Fragment lengths and the putative identity of recognizable peaks are given

not distinguish samples collected at $5 \mathrm{~m}$ from those at $80 \mathrm{~m}$ within or between stations (data not shown).

To test if the variance in the presence and absence of particular peaks between different samples ( $y$-variables, nasA gene populations) was related to bacterial production, chlorophyll $a$, bacterial biomass, cell activity (measured via fluorescent in situ hybridization), or $\mathrm{NO}_{3}{ }^{-}$or $\mathrm{NH}_{4}{ }^{+}$concentrations (x-variables), a PLS regression model was constructed (Fig. 3). Fig. 3 shows a 2D scatter plot of the $x$-loading weights and $y$-load- ings for 2 specified components from PLS. Generally, predictors ( $x$-variables) that are projected positively along the $x$-axis are positively correlated with the variability in the population of response variables. $\mathrm{NH}_{4}{ }^{+}$ concentration, percent activity, and $\mathrm{NO}_{3}{ }^{-}$concentration were positively correlated with the observed variability in the relative abundance and presence or absence of the nasA TRFs. Biomass, bacterial productivity, and chlorophyll a were negatively correlated with the variability in the population of nasA TRFs. 


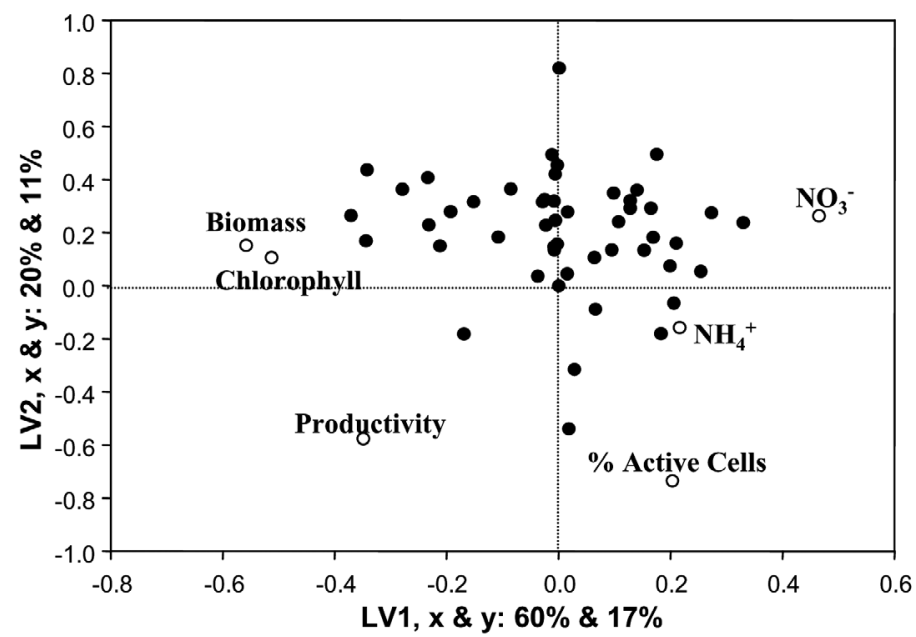

Fig. 3. Partial least-squares model weight-vector plot for predictor $(x)$ variables and the response variables for the first (LV1) and second (LV2) latent variables. Each circle represents a unique T-RFLP fragment. Labels on the $x$ - and $y$-axes indicate that in the first dimension (component) of the data, $60 \%$ the variation in the $x$-variables explains $17 \%$ of the variation in the $y$-variables. In the second dimension (component), another $20 \%$ of the variance in the $x$-variables explains an additional $11 \%$ of the variation in the $y$-variables same clade, which is composed entirely of Barents Sea clones (Fig. 4, Barents Sea Groups 1 and 2). Only Barents Sea Group 1 and Group 2 sequences that are completely unique are presented in the Barents Sea Group 1 and Group 2 clade to conserve space. One very

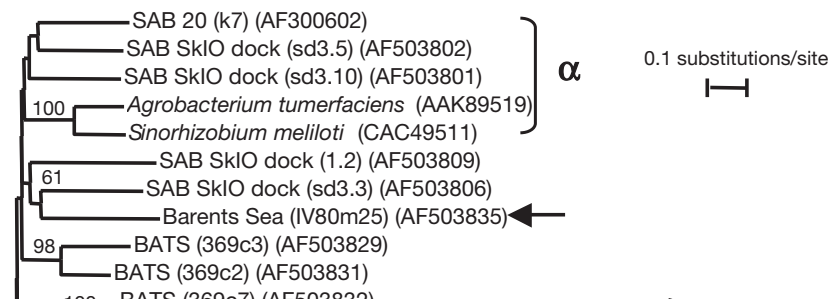

100 BATS (369C7) (AF503832)

$55 \quad 100-$ SAB 35 (3m1) (AF300580)

LSAB 35 (3m3) (AF300582)

100 Barents Sea Isolate (Pseudoalteromonas sp.) (AF300608) Barents Sea Isolate (Pseudoalteromonassp.) (AF503852) Wilmington River (yy5) (AF300603)

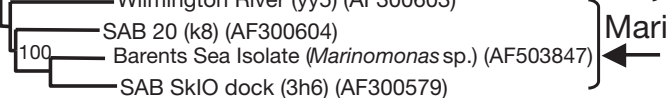

SAB SkIO dock (3h6) (AF300579)

100 -BATS (369c6) (AF503830)

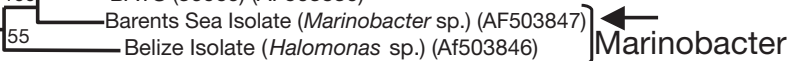
Norwegian Fjord (AF503844)

96 Barents Sea (III5m23) (AF503836)

100 Barents Sea (V80m2) (AF503838)

Barents Sea (V80m15) (AF503863)

100 Barents Sea (III5m22) (AF503864) Barents Sea (III5m36) (AF503841)

100 _ Barents (III5m8) (AF503839)

Barents Sea (V80m9) (AF503840)

Barents Sea Group 1

Although $\mathrm{NH}_{4}{ }^{+}$concentration and percent activity were each positively correlated with the variability associated with nasA populations, most of the TRFs are clustered in the upper right quadrant, close to $\mathrm{NO}_{3}{ }^{-}$ concentration. This is a strong indication that more of the TRFs are highly correlated with $\mathrm{NO}_{3}{ }^{-}$and that $\mathrm{NO}_{3}{ }^{-}$was the most important variable in explaining the variation in nasA TRFs. Analysis of the regression coefficient for every combination of independent variable and terminal restriction fragment indicated that $\mathrm{NO}_{3}{ }^{-}$was a better predictor of nasA community structure than any of the other variables modeled by a factor 10 , suggesting that nasA populations are influenced by variability in $\mathrm{NO}_{3}{ }^{-}$concentration.

\section{nasA sequence diversity in the Barents Sea (analysis of clone libraries and identification of T-RFLP peaks)}

From the 4 libraries, 55 clones were analyzed and sequenced. Sequences from the clone libraries were analyzed and compared to nasA sequences from clones and isolates available in GenBank. A total of 52 out of 55 of the sequenced clones grouped within the

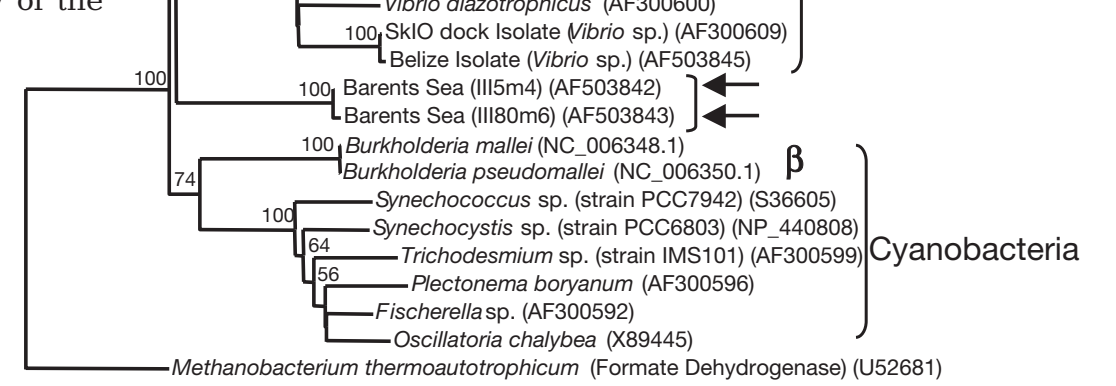

Fig. 4. Inferred phylogenetic relationships of nas $A$ - and narB-encoded amino acid sequences from heterotrophic bacteria and cyanobacteria, respectively. Bootstrap values $>50$ (out of 100) are shown. Scale bar indicates 0.1 fixed amino acid substitutions per site. The amino acid sequence of formate dehydrogenase from Methanobacterium thermoautotrophicum (GenBank Accession No. U52681), a putative evolutionary ancestor of the proteins encoded by the nasA and narB genes, was used to root the tree. All of the nasA sequences from clones and isolates collected in the Barents Sea are indicated with arrows. All nas $A$ GenBank accession numbers are given next to their designated sequence 
deeply rooted clade was comprised only of 2 Barents Sea clones (Barents Sea Clones III5m4 and III80m6). An additional Barents Sea clone (IV80m25) grouped with clones sequenced from samples collected in the Skidaway River estuary and has a sister-group that includes members of the alpha-Proteobacteria.

The largest peaks in all of the T-RFLP electropherograms corresponded to TRFs that can be assigned to the Barents Sea Group-1 and -2 clades, which do not contain cultured representatives (i.e. the clade is of unknown phylogenetic identity). Three commonly identified groups by T-RFLP were the unknown Barents Sea group, and groups related to Marinobacter and Vibrio sp. (Fig. 2). Each of these groups contains representatives that yielded different putative TRFs that could be identified in electropherograms. Some of the other common TRFs observed in this study have putative TRF lengths, corresponding to clones or isolates in clades typified by Pseudoalteromonas sp., Marinomonas sp., Psychrobacter sp., and the deeply rooted Barents Sea Clones III5m4 and III80m6, which are of unknown phylogenetic identity.

\section{SYBR green PCR assay}

To evaluate the specificity of the quantitative PCR reactions, PCR products were analyzed with meltcurve analysis and inspected on agarose gels (data not shown). For both primer sets the PCR amplicon dissociated as a solitary peak, indicating that the PCR reaction was specific for the intended target. Also,

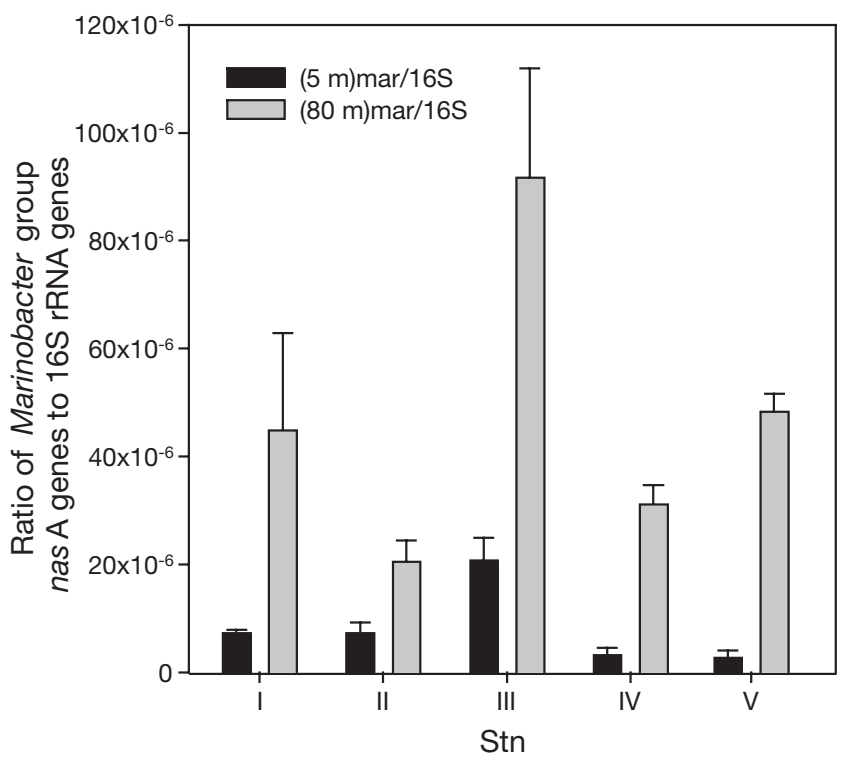

Fig. 5. Ratio of Marinobacter sp. nasA genes to $16 \mathrm{~S}$ rRNA genes at 5 and $80 \mathrm{~m}$ at the 5 transect stations melt-curve analysis and repeated examination of PCR reactions on agarose gels did not reveal any primer-dimer formation, which suggests that the increase in SYBR green fluorescence during PCR amplification is attributable to an increase of the intended target. The SYBR green PCR assays optimized in this study consistently produced linear standard curves with slopes around -3.3, which indicated that all of the reactions were amplifying at approximately the same rate and therefore with an efficiency close to 1.

To evaluate the specificity of the Marinobacter sp. group nasA primers, DNA from $80 \mathrm{~m}$ at Station IV was amplified, a clone library was constructed, and 10 clones were sequenced. All of the sequences were identical and contained motifs that are unique to Marinobacter sp. sequences, indicating that the primers are specific for the Marinobacter sp. nasA group. Marinobacter sp. nasA gene copy number per picogram of DNA was approximately an order of magnitude higher for all of the $80 \mathrm{~m}$ samples compared to each of the $5 \mathrm{~m}$ samples. Relative to total cell abundance, there was, on average, an 8-fold difference in Marinobacter nasA genes at $80 \mathrm{~m}$ compared to $5 \mathrm{~m}$ (Fig. 5). Across all stations this result was significant (ANOVA, $\mathrm{p}<0.01$ ). Also, $\mathrm{NO}_{3}{ }^{-}$concentrations were substantially higher for all of the $80 \mathrm{~m}$ samples compared to the $5 \mathrm{~m}$ samples (Table 1 ).

\section{DISCUSSION}

Real-time PCR and T-RFLP assays both suggest that the distribution and abundance of populations of nasAcontaining bacteria are influenced strongly by $\mathrm{NO}_{3}{ }^{-}$ availability. This is not necessarily an intuitive finding, because $\mathrm{NO}_{3}{ }^{-}$is the most oxidized and energetically least preferred common nitrogen source available to bacteria in marine environments (Vallino et al. 1996). Thus, one might predict that the distribution and abundance of nasA-containing bacteria are always primarily driven by the availability of other resources, such as carbon substrates, to the extent that there is not a discernable relationship between $\mathrm{NO}_{3}{ }^{-}$resource availability and nasA abundance and community structure. These findings suggest that $\mathrm{NO}_{3}{ }^{-}$availability is sufficiently strong enough to influence the structure of aerobic heterotrophic bacterioplankton communities.

nasA gene fragments from Barents Sea isolates group into a larger number of clades than the nasA gene fragments recovered from Barents Sea clone libraries. Two Pseudoalteromonas sp. isolates retrieved from the Barents Sea clustered with clones retrieved from Hawaiian Ocean Time Series (HOTS), Bermuda Atlantic Time Series (BATS), South Atlantic Bight (SAB) mid-shelf samples, and with 3 isolates collected 
from the Sargasso Sea. Marinomonas sp. strains from the Barents Sea and Marinobacter sp. typify major clades of nasA clones, and the nasA sequence from a Psychrobacter sp. isolate was not closely related to any of the other sequences. Of the 9 major nas $A$ clades described to date (Allen et al. 2001; Fig. 4), 4 do not have cultured representatives and 2 of those consist only of Barents Sea clones. Most of the major clades of nasA genes identified up to this point can be putatively assigned to the gamma-Proteobacteria. This observation is in agreement with 2 other studies that used $16 \mathrm{~S}$ rRNA as a marker to track significant increases in the abundance of gamma-Proteobacterial populations following the addition of $\mathrm{NO}_{3}{ }^{-}$to seawater mesocosms (Joint et al. 2002, Ovreas et al. 2003).

It is important to emphasize, however, that, for most of the major groups of cultured organisms that appear to be dominant in terms of $\mathrm{NO}_{3}{ }^{-}$assimilation in the marine environment (i.e. Vibrio sp., Marinobacter sp., Alteromonas sp.), highly related strains (i.e. 98 to $100 \%$ identity for complete $16 \mathrm{~S}$ rRNA sequences) that are nasA-negative and do not display the $\mathrm{NO}_{3}{ }^{-}$assimilation phenotype have also been cultured (Allen et al. 2001). Therefore, $16 \mathrm{~S}$ rRNA-based molecular assays designed to provide information about the activity and distribution of Marinobacter sp. or Vibrio sp. would not necessarily reveal important information about populations of bacterioplankton that may be responsible for a substantial fraction of the total pelagic $\mathrm{NO}_{3}{ }^{-}$uptake.

Because the sampling transect in this study included several different water masses, it is not surprising that T-RFLP analysis revealed that the southern North Atlantic stations (I and II) and the MIZ stations (III, IV, and V) had distinct nasA populations. It is especially interesting, however, that these differences are also reflected in differences in the overall pattern of DIN utilization across the transect. According to measurements of ${ }^{15} \mathrm{~N}$ uptake and bacterial productivity, DIN (and $\mathrm{NO}_{3}{ }^{-}$specifically) was a much more important $\mathrm{N}$ resource for bacteria in the MIZ stations compared to the North Atlantic stations; at Stns I and II, DIN supported 5 and $10 \%$ of bacterial $\mathrm{N}$ production, respectively, while DIN accounted for between 39 and $54 \%$ of bacterial $\mathrm{N}$ demand at Stns III to V. $\mathrm{NH}_{4}$ uptake generally dominated DIN assimilation and accounted for between 66 and $80 \%$ of bacterial DIN demand, but $\mathrm{NO}_{3}{ }^{-}$ was a relatively more important $\mathrm{N}$ source when overall DIN was more important: at $80 \mathrm{~m}$ compared to $5 \mathrm{~m}$ depth and in MIZ compared to North Atlantic waters. At $\mathrm{NO}_{3}{ }^{-}$concentrations of $>5 \mu \mathrm{M}, \mathrm{NO}_{3}{ }^{-}$always accounted for at least $20 \%$ of bacterial DIN assimilation (Allen et al. 2002). The real-time PCR and T-RFLP assay indicated that communities of nasA-containing bacteria were more abundant at $80 \mathrm{~m}$ and generally more diverse in the MIZ segment of the transect, and in both circumstances bacteria were estimated to rely much more heavily on $\mathrm{NO}_{3}{ }^{-}$as a source for $\mathrm{N}$ production.

The total bacterial community uptake of $\mathrm{NO}_{3}{ }^{-}$along the sampling transect estimated from ${ }^{15} \mathrm{~N}$ experiments is generally between $5 \times 10^{4}$ and $5 \times 10^{5} \mathrm{fg} \mathrm{N}^{-1} \mathrm{~d}^{-1}$ (Allen et al. 2002). If, on average, the bacterial population along the transect was doubling 0.5 times daily (Howard-Jones et al. 2002), bacteria contained $5 \mathrm{fg} \mathrm{N}$ cell ${ }^{-1}$, and $\mathrm{NO}_{3}{ }^{-}$accounts for $10 \%$ of their $\mathrm{N}$ diet, it

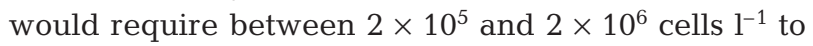
clear between $5 \times 10^{4}$ and $5 \times 10^{5} \mathrm{fg} \mathrm{N}^{-1} \mathrm{~d}^{-1} \mathrm{NO}_{3}{ }^{-}$. The real-time PCR assays indicated that the ratio of the nasA-containing population to total bacteria was between $1 \times 10^{-4}$ and $2 \times 10^{-5}$. Generally, Marinobacter sp. organisms accounted for $10 \%$ of the total nasA T-RFLP peak height. In a population that was generally around $1 \times 10^{9}$ total bacteria $1^{-1}$ (Howard-Jones et al. 2002), we estimate that the population of nasA-containing bacteria was between $2 \times 10^{5}$ and $1 \times 10^{6} \mathrm{l}^{-1}$. Therefore, our estimates of the population size of nasA-containing bacteria are appropriate and within the range of what we would expect based on ${ }^{15} \mathrm{~N}$-tracer studies, bacterial growth rates, and bacterial $\mathrm{N}$ demand. It appears, therefore, that a relatively minor fraction of the total bacteria is capable of having a large impact on specific components of the pelagic $\mathrm{N}$ cycle.

nasA-containing heterotrophic bacteria represent a biogeochemically important fraction of the total bacterioplankton, because they represent a possible $\mathrm{NO}_{3}{ }^{-}$sink that does not involve incorporation of $\mathrm{CO}_{2}$. This study reveals that nasA populations do, in fact, respond in terms of abundance and changes in community structure to $\mathrm{NO}_{3}{ }^{-}$resource availability. Previously, we might have hypothesized that most bacteria are capable of $\mathrm{NO}_{3}{ }^{-}$uptake, but only occasionally exhibit the phenotype because of the energetic costs associated with $\mathrm{NO}_{3}{ }^{-}$uptake. The results presented here suggest that specific groups of nasApositive bacteria are associated with high levels of $\mathrm{NO}_{3}{ }^{-}$and that detectable changes in nasA population community structure occur as a result of changes in patterns of $\mathrm{NO}_{3}{ }^{-}$supply.

Acknowledgements. This research is dedicated by A.E.A. in loving memory of K.E.A. We thank C. Wexels-Riser, M. Registad, and S. Øygarden for their efforts in cruise preparation and Heidi Hammerstein for expert laboratory assistance. We also thank Paul Wassmann for the invitation to participate in the research expedition and for being such an accommodating host. Thanks also to Hope-Howard Jones for help with cruise preparation, sample collection, and transport. Also, we acknowledge the captain and crew of the RV 'Jan Mayen' for logistic support and excellent meals. Thanks also to Bess Ward for useful comments regarding the content of this manuscript. This research was supported by NSF Grants OCE-95-21086 and 99-82133 and DOE Grants FG0288ER62531 and FG02-98ER62531 


\section{LITERATURE CITED}

Allen AE, Booth MG, Frischer ME, Verity PG, Zehr JP, Zani S (2001) Diversity and detection of nitrate assimilation genes in marine bacteria. Appl Environ Microbiol 67: 5343-5348

Allen AE, Howard-Jones MH, Booth MG, Frischer ME, Verity PG, Bronk DA, Sanderson MP (2002) Importance of heterotrophic bacterial assimilation of ammonium and nitrate in the Barents Sea during summer. J Mar Syst 38:93-108

Boynton WR, Garber JH, Summers R, Kemp WM (1995) Inputs, transformations, and transport of nitrogen and phosphorus in Chesapeake Bay and selected tributaries. Estuaries 18:285-314

Dadou I, Lamy F, Rabouille C, Ruiz-Pino D, Anderson V, Bianchi M, Garcon V (2001) An integrated biological pump model from the euphotic zone to the sediment: a 1-D application in the northeast tropical Atlantic. DeepSea Res II 48:2345-2381

Fasham M, Ducklow H, McKelvie S (1990) A nitrogen-based model of plankton dynamics in the oceanic mixed layer. J Mar Res 48:591-639

Haupt O, Wolf U, Bodungen B (1999) Modeling the pelagic nitrogen cycle and vertical particle flux in the Norwegian Sea. J Mar Syst 19:173-199

Higuchi R, Dollinger G, Walsh PS, Gelfand DH (1991) Simultaneous amplification and detection of specific DNA sequences. BioTechnology 10:413

Howard-Jones MH, Verity PG, Frischer ME (2000) Determining the physiological status of individual bacterial cells. In: Paul JH (ed) Methods in microbiology, Vol 30. Marine microbiology. Academic Press, London

Howard-Jones MH, Ballard VD, Allen AE, Frischer ME, Verity PG (2002) Distribution of bacterial biomass and activity in the marginal ice zone of the central Barents Sea in summer. J Mar Syst 38:77-91

Joint I, Henriksen P, Fonnes GA, Bourne D, Thingstad TF, Riemann B (2002) Competition for inorganic nutrients between phytoplankton and bacterioplankton in nutrient manipulated mesocosms. Aquat Micob Ecol 29:145-159

Kirchman DL (1994) The uptake of inorganic nutrients by heterotrophic bacteria. Microb Ecol 28:255-271

Editorial responsibility: Dittmar Hahn,

San Marcos, Texas, USA
Kirchman DL (2000) Uptake and regeneration of inorganic nutrients by marine heterotrophic bacteria. In: Kirchman DL (ed) Microbial ecology of the oceans. John Wiley \& Sons, New York, p 261-288

Kirchman DL, Moss J, Keil RG (1992) Nitrate uptake by heterotrophic bacteria: does it change the $f$-ratio? Arch Hydrobiol 37:129-138

Legendre L, Grosselin M (1989) New production and export of organic matter to the deep ocean: consequences of some recent discoveries. Limnol Oceanogr 34:1374-1380

Middelburg JJ, Nieuwenhuize J (2000) Nitrogen uptake by heterotrophic bacteria and phytoplankton in the nitraterich Thames estuary. Mar Ecol Prog Ser 203:13-21

Olivieri RA, Chavez FP (2000) A model of plankton dynamics for the coastal upwelling system of Monterey Bay, California. Deep-Sea Res II 47:1077-1106

Ovreas L, Bourne B, Sandaa RA, Casamayor E and 5 others (2003) Response of bacterial and viral communities to nutrient manipulations in seawater mesocosms. Aquat Microb Ecol 31:109-121

Ririe KM, Rasmussen RP, Wittwer CT (1997) Product differentiation by analysis of DNA melting curves during the polymerase chain reaction. Anal Biochem 270:154-160

Rodrigues RM, Williams PJ (2002) Inorganic nitrogen assimilation by picoplankton and whole plankton in a coastal ecosystem. Limnol Oceanogr 47:1608-1616

Thompson JD, Higgins DG, Gibson TJ (1994) CLUSTAL W: improving the sensitivity of progressive multiple sequence alignment through sequence weighting, positions-specific gap penalties and weight matrix choice. Nucleic Acids Res 22:4673-4680

Vallino JJ, Hopkinson CS, Hobie JE (1996) Modeling bacterial utilization of dissolved organic matter: optimization replaces Monod growth kinetics. Limnol Oceanogr 41: 1591-1609

Van de Peer V, De Wachter R (1997) Construction of evolutionary distance trees with TREECON for Windows: accounting for variation in nucleotide substitution rate among sites. Comput Applic Biosci 13:227-230

Wittwer CT, Hermann MG, Moss AA, Rasmussen RP (1997) Continuous monitoring of rapid cycle DNA amplification. BioTechniques 22:130-138

Submitted: June 3, 2003; Accepted: April 1, 2005

Proofs received from author(s): June 11, 2005 